\title{
Performance of sunflower (Helianthus annuus L.) genotypes morphological and yield traits under water deficit conditions
}

Faiza Khatoon Rajper ${ }^{1}$, Wajid Ali Jatoi ${ }^{1 *}$, Qurban Ali Channa ${ }^{1}$, Shahnaz Memon $^{2}$, Nasreen Fatima ${ }^{1}$, Muhammad Ali Ansari ${ }^{3}$, Muhammad Mithal Lund $^{3}$, Hafeez Ali Bhatti ${ }^{4}$, Soorath Keerio ${ }^{3}$ and Kanwal Mirani ${ }^{5}$

1. Department of Plant Breeding and Genetics, Sindh Agriculture University Tandojam, Pakistan

2. Cotton Research Insitute, Tandojam, Pakistan

3. Department of Agronomy, Sindh Agriculture University Tandojam, Pakistan

4. Department of Biotechnology, Sindh Agriculture University Tandojam, Pakistan

5. Department of Horticulture, Sindh Agriculture University Tandojam, Pakistan

*Corresponding author's email: jatoiwajid@yahoo.com

Citation

Faiza Khatoon Rajper, Wajid Ali Jatoi, Qurban Ali Channa, Shahnaz Memon, Nasreen Fatima, Muhammad Ali Ansari, Muhammad Mithal Lund, Hafeez Ali Bhatti, Soorath Keerio and Kanwal Mirani. Performance of sunflower (Helianthus annuus L.) genotypes morphological and yield traits under water deficit conditions. Pure and Applied Biology. Vol. 11, Issue 1, pp79-91. http://dx.doi.org/10.19045/bspab.2022.110009

\begin{tabular}{llll}
\hline \hline Received: 25/02/2021 & Revised: 23/04/2021 & Accepted: 06/05/2021 & Online First: 17/05/2021 \\
\hline \hline
\end{tabular}

\section{Abstract}

The current research finding is carried out for developing the water tolerant genotypes thus the six sunflower genotypes such as Charinka, Thatta, A-2,TJ-1,N-17 and A-1 were studied at oilseeds research institute, Tandojam during 2019.The experiment was carried out in split plot design with three replications. Twelve quantitative traits were studied such as days to $75 \%$ flowering, day to $75 \%$ maturity, hight, head size, number of seeds head ${ }^{-1}$, seed index, relative water content, leaf area, head mass, mass of achenes head ${ }^{-}$ ${ }^{1}$,plant dry matter and harvest index. The mean square from analysis variance displayed that genotypes, treatments and treatments $\mathrm{x}$ genotypes were significant for all the traits like days to $75 \%$ heading, days to $75 \%$ maturity, plant height, number of seeds head ${ }^{-1}, 1000$-seed weight, relative water content, leaf area, biological yield plant $^{-1}$, head mass, mass of achenes head ${ }^{-1}$ and harvest index. Water stress caused significant impacts on all the studies traits, like days to $75 \%$ heading, days to $75 \%$ maturity, plant height, number of seeds head ${ }^{-1}, 1000$-seed weight, relative water content, leaf area, biological yield plant $^{-1}$, head mass, mass of achenes head ${ }^{-1}$ and harvest index. Among the genotypes such as A-2,A-1 and TJ-1 performed better under water stress conditions according to higher mean performance for days to $75 \%$ heading, day to $75 \%$ maturity, plant height, head size, number of seed head ${ }^{-1}, 1000$ seed weight, relative water content, leaf area, total dry matter, head mass, mass of achenes ${ }^{-1}$ and harvest index. Seed yield significant negative $(-0.49 *)$ associated with days to $75 \%$ flowering, $(-0.57 *) 1000$-seed weight and $\left(-0.44^{*}\right)$ relative water content. The seed yield plant ${ }^{-1}$ was significant positive $\left(0.90^{* *}\right)$ associated with harvest index. Whereas in water stress condition seed yield significant negative $\left(-0.40^{*}\right)$ associated with plant height and $\left(-0.36^{*}\right)$ head mass and it was significant positive $\left(0.44^{*}\right)$ with head diameter, $\left(0.73^{* *}\right)$ seeds per head, $(0.87 * *)$ 1000 -seed weight and $(0.78 * *)$ harvest index.

Keywords: Morphology; Sunflower; Yield traits and Water deficit 


\section{Introduction}

Sunflower (Helianthus annuus L.) is the world's more valuable crop and have achieved prestige among all oilseed crops. This is easily growing and profitable at small farm and large field scale [1]. This is called high-grade oil because it contains protein 20$27 \%$, huge source of vitamins $\mathrm{A}$ and $\mathrm{D}$, oleic acid (16.2\%), linoleic acid (72.5\%) and greater amount of polyunsaturated fatty acid (60\%), make it excellent edible vegetable oil (Tahir et al., 2014), also have anti-cholesterol properties, the ability to fit change circumstances, short period, vast adaptation towards soil and climate patterns, photo and thermo-insensitiveness, drought resistant also gives maximum oil production per unit area. This crop is cultivated 2.4 million hectares for 1.44 million tons production with yield performance was $6.08 \mathrm{q} \mathrm{ha}^{-1}$ in contrast $12.71 \mathrm{q} \mathrm{ha}^{-1}$ to the world production [2].

The sunflower seed cake used for cattle feed and also used in industry for making paints, cosmetics, decorations, medical uses [3, 4] and its dried stalk used for fuel [5].The water is getting less day by day, because nonavailability of natural rainfall, too much draw out of groundwater, rise in the number of inhabitant and greater water usage for farming [6-9]. Drought stress is the key factor has destructive effect on the production and oil seed quality [10], modify plant development, physiology and metabolic functions [11].

Drought is a meteorological term and is commonly defined as a period without significant rainfall. Generally, drought stress occurs when the available water in the soil is reduced and atmospheric conditions cause continuous loss of water by transpiration or evaporation. Drought stress tolerance is seen in almost all plants, but its extent varies from species to species and even within species. Water deficit and salt stresses are global issues to ensure survival of agricultural crops and sustainable food production [12]. Conventional plant breeding attempts have changed over to use physiological selection criteria since they are time consuming and rely on present genetic variability [13]. Tolerance to abiotic stresses is very complex, due to the intricate of interactions between stress factors and various molecular, biochemical and physiological phenomena affecting plant growth and development [14]. High yield potential under drought stress is the target of crop breeding. In many cases, high yield potential can contribute to yield in moderate stress environment [15]. Drought stress is considered to be a moderate loss of water, which leads to stomatal closure and limitation of gas exchange. Desiccation is much more extensive loss of water, which can potentially lead to gross disruption of metabolism and cell structure and eventually to the cessation of enzyme catalyzed reactions [16, 12]. Drought stress is characterized by reduction of water content, diminished leaf water potential and turgor loss, closure of stomata and decrease in cell enlargement and growth. Severe water stress may result in the arrest of photosynthesis, disturbance of metabolism and finally the death of plant [17].

The plant best growth with temperatures at $20-25^{\circ} \mathrm{C}$, while seed yields and oil content declined at temperatures of above $25^{\circ} \mathrm{C}$ [18]. Plants are tolerant to water deficit, so when exposed to drought stress duration the key developing and flowering stages, production and oil content decreased [19, 20].

Sunflower seeds production was 43.8 million metric tons at 24.8 million hectares of acreage [21], along total production of 1,249 $\mathrm{kg}$ ha-1 [22]. However, under water stress conditions, sunflower efficiency decreases $[23,24]$. The head diameter, number of achenes per head, weight of 1000 achenes and sunflower hybrid production dropped drastically [25]. In order to better understand crop growth and development, crop 
phenology is fundamental and speedily influences of a lot of agricultural management practices. Water scarce is the environmental condition that reducing or prolonging the development process that may impact crop phenology [26].

The scarcity of water at various stages of sunflower growth causes a major decrease in the yield of seeds, alters the composition of the seeds, reduces oil quality and oil yield grains [27-29]. Moreover, a temporary or permanent insufficient water supply will adversely affect the morphological, physiological and biochemical processes in sunflower [30]. The excess irrigation will decrease the oil and oleic acid and enhance linoleic acid; both oil and oleic acid was greatest with irrigation of about 500 to 600 $\mathrm{mm}[31]$.

In sunflower breeding with increased yield performance, it is crucial to seek morphological and physiological characteristics, that are readily optimized of correlate with seed productivity and oil yield, so that they can be utilized as selection process [32]. Under deficit irrigation, the genotype has the good performance. The initial phase of growth was much successful than middle and later stage in irrigation to increase the seed yield [33]. On the basis of previous literature cited regarding the importance of sunflower crop for higher seed yield and oil content. The present study is planning to evaluate yield performance of sunflower genotypes under water deficit conditions.

\section{Materials and Methods}

The present research was conducted to carried out the experimental field of oilseeds Research Institute Tandojam, during rabi season 2019-2020.The experiment was held in split plots with three replications. Two irrigation regimes i.e., $\mathrm{T}_{1}$ (control maximum 4 irrigations) and $\mathrm{T}_{2}$ (zero irrigation) considered as main plots and genotypes as sub-plots. Six parental lines such as
Charinka, Thatta, A-2,TJ-1,N-17 and A-1 for twelve quantitative traits such as days to $75 \%$ flowering, days to $75 \%$ maturity, height, head size, number of seeds head ${ }^{-1}$,seed index, relative water content, leaf area, head mass, mass of achenes head ${ }^{-1}$,plant dry matter and harvest index. were studied. The obtained data was statistical analyzed according to [34], and correlation coefficient was calculated according to [35].

\section{Results and Discussion}

Present studies were aimed to determine the effect of water stress in six lines of sunflower for twelve yield and physiological traits under the agro-climatic conditions at the experimental field of oil seeds research institute, Tandojam. The obtained result is described here under which are as under

Analysis of variance for yield and physiological traits

The analysis of variance (Table 1) and separate ANOVA of non-stress and water stress (Table 2) showed that treatment and genotypes were significant for all traits such as flowering days, maturity days, height, head size, seeds head ${ }^{-1}$, thousand seed weight, relative water content, leaf area, biological yield, head mass, mass of achenes head ${ }^{-1}$ and harvest index. Whereas treatment $\mathrm{X}$ genotypes ( $\mathrm{T} \times \mathrm{G})$ were also significant for most of the traits except plant height and head diameter. The separates ANOVA of nonstress and water stress were also showed that genotypes were significant for all the traits in both the environments. The significance of variances revealed that genotypes implemented inconsistently for yield and physiological traits under both the environment as well as across the environments [36, 37]. They also reported significance mean squares for yield and physiological traits.

Mean performance of sunflower genotypes Days to $75 \%$ flowering

Averagely -4.16 days reduced in days to $75 \%$ flowering under water stress condition. In 
non-stress days to $75 \%$ flowering was ranged from 49.00 to 56.00 and 45.00 to 52.00 in water stress condition (Table 3 ). The TJ-1 takes minimum days to $75 \%$ flowering followed by $\mathrm{N}-17$ and Thatta in non- stress condition. While A-1 takes maximum days to $75 \%$ flowering is non stress. Whereas in water stress condition Charnika, TJ-1and Thatta took minimum days to $75 \%$ flowering and A-1takes maximum days to $75 \%$ flowering in water stress condition. Similar results were obtained by [38-40]. Observed that water stress caused early flowering.

\section{Days to $75 \%$ maturity}

Days to $75 \%$ maturity was ranged from 132.00 to 134.33 is non-stress. The genotypes like Thatta , A-1 and N-17 takes minimum days to $75 \%$ maturity and Charnika takes maximum days to $75 \%$ maturity is non stress (Table 3). Whereas in water stress, A2 A-1 and Charnika takes minimum days to $75 \%$ maturity and $\mathrm{N}-17$ take more days to $75 \%$ maturity. From present results it is suggested that such genotypes which takes minimum days to $75 \%$ maturity in water stress condition may be prepared for breeding programme [38-40]. Examined that water stress declined in days to maturity.

\section{Plant height (cm)}

The on an average $-18.28 \mathrm{~cm}$ plant height was declined due to water stress condition. Nonetheless genotype Thatta A-2 and N-17 gave minimum relative decreased for plant height in water stress conditions (Table 4). The A-2 gave minimum plant height is both the conditions and Thatta showed tallers plants is non-stress and water stress conditions [41, 40]. Studied that under adverse conditions shorter plant structure were found in sunflower genotypes.

\section{Head diameter $(\mathbf{c m})$}

Wider heads with a greater number of seeds are desirable for obtain higher yield in sunflower. On an average water stress caused $-6.53 \mathrm{~cm}$ averaged declined in head diameter in all genotypes (Table 4). Among the genotypes TJ -1, A-1 and N-17 showed minimum relative decreased in head diameter in water stress conditions. While Thatta displayed maximum head diameter in nonstress and TJ-1 showed wider heads in water stress conditions. It is concluded that those genotypes gave minimum relative decrease with desirable head size in water stress conditions could be grouped as water stress tolerant and those genotypes declined maximum relative decreased and smaller head size could be placed in water stress susceptible genotypes. Similarly, [40, 42-44]. They also reported that water stress caused a declined in head diameter.

Number of seeds head ${ }^{-1}$

The number of seeds head ${ }^{-1}$ is varied from 908.33 to 725.00 in non- stress and 731.67 to 566.67 in water stress condition which caused -92.66averaged declined in seeds per head due to water stress condition. Among the genotypes, A-2, Charnika Thatta and A-1 gave more seeds head ${ }^{-1}$ in non-stress and water stress condition (Table 5). It is suggested that above cited genotypes should be utilized for the development of water stress tolerant genotypes with improved seeds per head. Similarly, [33, 40, 42-44]. They also reported similar type of results.

\section{0- seeds weight}

Water stress caused a significant declined in 1000-seed weight also although A-2, N 17and A-1 these genotypes declined minimum in seed index and such genotypes prove their tolerant ability under zero irrigation. It is further suggested that such genotypes were water stress tolerant for seed index (Table 5). Our results were agreement with those who have obtained similar results such as $[33,40,42-44]$. Observed that under shortage of water or zero irrigation caused a significant loss of 1000-seed weight.

\section{Relative water content (\%)}

The range of RWC was 71.00 to $80.00 \%$ in non- stress and 36.00 to $50.00 \%$ in water stress condition which showed $-32.94 \%$ 
averaged was reduced due to water stress condition. A-2 A-1 and Thatta gave more RWC in non-stress and in water stress Thatta, A-1 and Charnika retained maximum RWC (Table 6) [45]. He also reported that under stress condition those genotypes which possessed a good amount of water in their leaves they showed that tolerant ability against the stress condition and such genotypes could be grown in those areas where growers facing the water shortage problem.

\section{Leaf area $\left(\mathrm{cm}^{2}\right)$}

The leaf area is varied from 36.06 to 38.23 in non- stress and it was ranged from 23.00 to $32.00 \mathrm{~cm}^{2}$ in water stress condition. A-1, A-2 and TJ-1 gave maximum leaf area in nonstress and water stress [45]. He observed that a sharper declined in leaf area was observed under zero irrigation or water stress conditions.

\section{Head mass (g)}

On an average -74.44 $\mathrm{g}$ head mass declined due to water stress condition (Table 7). The range of relative decreased in head mass was varied from -44.67 to $-109.00 \mathrm{~g}$ due to water stress however Charnika, Thatta, TJ-1 and N17 gave minimum relative decreased in head mass reduced to water stress. Whereas A-2 gave maximum reduction in head mass under water stress conditions $[33,40,42-44]$. They also reported similar type of results.

\section{Mass of Achenes head-1 (g)}

The seeds yield head ${ }^{-1}$ was varied from 58.40 to $82.00 \mathrm{~g}$ in non- stress and 32.00 to $46.33 \mathrm{~g}$ in water stress condition which showed 29.96 averaged declined in yield due to water stress condition (Table 7). Among the genotypes, A-2, Charinika and TJ-1 gave highest seeds yield in non-stress and water stress condition. It is suggested that above genotypes such as A-2, Charinika and TJ-1 were proved as water stress tolerant genotypes and they produced maximum seed yield under both the environment $[33,40,42$ 44]. They examined that a sharper declined in susceptible genotypes for seed yield while some genotypes showed a smaller amount of reduction in seed yield or mass of achenes per head those genotypes were placed in water stress tolerant group and they may be grown under zero irrigation or rain fall areas.

\section{Biological yield plant ${ }^{-1}(\mathrm{~g})$}

Biological yield plant $^{-1}$ was ranged from 206.33 to 256.00 in non- stress and 155.00 to $192.67 \mathrm{~g}$ in water stress condition which showed $-65.18 \mathrm{~g}$ averaged declined due to water stress condition. Among the genotypes, TJ-1, N-17 and Thatta gave highest in water stress condition (Table 8) [33, 40, 42-44]. Examined that total dry matter have unique position for the development of water stress tolerant material and also observed that more or less reduction in biological yield was noted under water stress condition.

\section{Harvest index (\%)}

A-2, A-1 and N-17 gave minimum relative decrease in harvest index due to water stress conditions (Table 8). The range of harvest index was 23.77 to $36.83 \%$ in non-stress and 19.09 to $28.40 \%$ in water stress condition $[33,40,42-44,46]$. Examined that water stress were also caused reduction in harvest index.

\section{Correlation coefficient of yield and physiological traits}

Seed yield was significant negative associated with days to $75 \%$ flowering, 1000seed weight and relative water content. Whereas seed yield plant $^{-1}$ was significant positive associated with harvest index. Whereas seed yield had non-significant positive with seeds per head, head mass and biological yield and non-significant negative associated with associated with days to $75 \%$ maturity, plant height, head diameter and leaf area in non-stress condition (Table 9). Whereas in water stress condition seed yield significant negative associated with plant height and head mass and it was significant positive with head diameter, seeds per head, 1000-seed weight and harvest index. While 
seed yield had non-significant positive associated with relative water content, biological yield and non-significant negative associated with days to $75 \%$ flowering, days to $75 \%$ maturity and leaf area. The significant correlations in stress condition indicated that seed yield plant-1 were increased due to increase in head diameter, seeds per head, 1000 -seed weight and harvest index while significant negative associations of seed yield with other traits showed that if seed yield increased these traits such as plant height and head mass were decreased that is also desirable association while other correlations either positive or negative they were nonsignificant with seed yield their increase or decrease in traits cannot imposed significant effect on seed yield. Our results are in agreement with those they also reported such type of association with seed yield in water stress condition as well as non-stress conditions they are $[47,45]$.

Table 1. Mean squares from analysis of variance for quantitative traits of sunflower Genotypes grown in non-stress and under water stress conditions

\begin{tabular}{|c|c|c|c|c|c|c|}
\hline \multirow[b]{2}{*}{ Traits } & \multicolumn{5}{|c|}{ Mean squares } & \multirow{2}{*}{$\begin{array}{c}\text { Error } \\
\text { (b) } \\
\text { (D.F.20) }\end{array}$} \\
\hline & $\begin{array}{l}\text { Replicatio } \\
\text { n (D.F. 2) }\end{array}$ & $\begin{array}{c}\text { Treatmen } \\
\text { t (D.F.1) }\end{array}$ & $\begin{array}{c}\text { Error (a) } \\
\text { (D.F. 2) }\end{array}$ & $\begin{array}{c}\text { Genotypes } \\
\text { (D.F.5) }\end{array}$ & $\begin{array}{c}\text { T X G } \\
\text { (D.F.5) }\end{array}$ & \\
\hline Days to $75 \%$ flowering & 0.52 & $256.25^{*}$ & 2.08 & $29.60 * *$ & $9.91 *$ & 2.70 \\
\hline Days to $75 \%$ maturity & 3.69 & $2116.0 * *$ & 3.08 & $29.04 * *$ & $17.20 *$ & 5.52 \\
\hline Plant height & 1.87 & $3006.69 * *$ & 18.47 & $355.65 * *$ & $47.47 * *$ & 1.40 \\
\hline Head diameter & 0.44 & $384.16^{*}$ & 4.60 & $8.82 * *$ & $3.84 *$ & 1.16 \\
\hline Number of seeds head ${ }^{-1}$ & 127.00 & $206722 * *$ & 856.00 & $2160 * *$ & $3814.00 * *$ & 437.00 \\
\hline 1000 seed weight & 4.33 & $6480.25 * *$ & 0.33 & $41.78 * *$ & $136.98 * *$ & 1.27 \\
\hline Relative water content & 4.11 & $968.03 * *$ & 0.78 & $70.63 * *$ & $39.29 * *$ & 1.51 \\
\hline Leaf area & 0.44 & $730.08 * *$ & 1.98 & $26.46 * *$ & $13.71 * *$ & 0.88 \\
\hline Biological yield plant ${ }^{-1}$ & 9.20 & $38979 * *$ & 3.00 & $1377.70^{* *}$ & $460.20 * *$ & 9.40 \\
\hline Head mass & 22.00 & $503225^{* *}$ & 7.20 & $1183.6^{* *}$ & $448.60 * *$ & 6.80 \\
\hline Mass of achenes head ${ }^{-1}$ & 3.18 & $8079.01 * *$ & 1.39 & $299.01 * *$ & $31.41 * *$ & 1.24 \\
\hline Harvest index & 1.00 & $343.11^{* *}$ & 0.44 & $109.27 * *$ & $4.64 * *$ & 0.41 \\
\hline
\end{tabular}

$* * *=\mathrm{P} \leq 0.01$ and 0.05 levels. 
Table 2. Mean squares from analysis of variance for different parameters of sunflower grown in normal and water stress conditions

\begin{tabular}{|c|c|c|c|c|c|c|}
\hline \multirow{3}{*}{ Traits } & \multicolumn{6}{|c|}{ Mean squares } \\
\hline & \multicolumn{3}{|c|}{ Non stress } & \multicolumn{3}{|c|}{ Water stress } \\
\hline & $\begin{array}{c}\text { Replication } \\
\text { (D.F.2) }\end{array}$ & $\begin{array}{c}\text { Genotypes } \\
\text { (D.F.5) }\end{array}$ & $\begin{array}{c}\text { Error } \\
\text { (D.F.10) }\end{array}$ & $\begin{array}{l}\text { Replication } \\
\text { (D.F.2) }\end{array}$ & $\begin{array}{c}\text { Genotypes } \\
\text { (D.F.5) }\end{array}$ & $\begin{array}{c}\text { Error } \\
\text { (D.F.10) }\end{array}$ \\
\hline Days to $75 \%$ flowering & 1.72 & $17.02 *$ & 4.65 & 0.88 & $22.58 * *$ & 0.75 \\
\hline Days to $75 \%$ maturity & 4.38 & 3.25 & 6.92 & 2.38 & $42.98 * *$ & 4.12 \\
\hline Plant height & 5.28 & $208.23 * *$ & 1.74 & 15.05 & $194.88 * *$ & 1.05 \\
\hline Head diameter & 3.49 & $5.51 *$ & 1.18 & 1.55 & $7.15 * *$ & 1.15 \\
\hline Number of seeds head & 164.70 & $12182.70 * *$ & 633.30 & 818.10 & $13238.90 * *$ & 241.40 \\
\hline 1000-seed weight & 3.50 & $155.96 * *$ & 1.56 & 1.16 & $22.80 * *$ & 0.96 \\
\hline Relative water content & 2.88 & $33.78 * *$ & 0.88 & 2.00 & $76.13 * *$ & 2.13 \\
\hline Leaf area & 0.86 & $2.11^{\mathrm{ns}}$ & 1.01 & 1.55 & $38.05^{*}$ & 0.75 \\
\hline Biological yield plant & 1.29 & $1327.51 * *$ & 10.38 & 10.88 & $510.35 * *$ & 8.35 \\
\hline Head mass & 21.05 & $1339.47 * *$ & 10.77 & 7.72 & $292.75 * *$ & 2.92 \\
\hline Mass of achenes head & 3.48 & $252.89 * *$ & 1.29 & 0.72 & $77.52 * *$ & 1.18 \\
\hline Harvest index & 0.73 & $64.66^{* *}$ & 0.37 & 0.71 & $49.24 * *$ & 0.45 \\
\hline
\end{tabular}

$* *, *=\mathrm{P} \leq 0.01$ and 0.05 levels

Table 3. Mean Performance for days to $75 \%$ flowering and days of $75 \%$ maturity of sunflower genotypes grown under stress and water stress condition

\begin{tabular}{|c|c|c|c|c|c|c|}
\hline \multirow{2}{*}{ Genotypes } & \multicolumn{2}{|c|}{ Days to $75 \%$ flowering } & \multirow{2}{*}{ R.D.* } & \multicolumn{2}{|c|}{ Days to $75 \%$ maturity } & \multirow[t]{2}{*}{ R.D* } \\
\hline & Non-stress & Water-stress & & Non-stress & Water-stress & \\
\hline Chanika & 53.66 & 45.00 & -8.66 & 134.33 & 116.00 & -18.33 \\
\hline Thatta & 53.00 & 48.00 & -5.00 & 131.67 & 119.33 & -12.34 \\
\hline A2 & 53.66 & 50.33 & -3.33 & 131.67 & 112.00 & -19.67 \\
\hline TJ-1 & 49.00 & 46.00 & -3.00 & 131.67 & 118.00 & -13.67 \\
\hline $\mathrm{N}-17$ & 51.33 & 50.33 & -1.00 & 132.67 & 122.67 & -10.00 \\
\hline A-1 & 56.00 & 52.00 & -4.00 & 132.33 & 114.33 & -18.00 \\
\hline Mean & 52.77 & 48.61 & -4.16 & 132.39 & 117.05 & -15.33 \\
\hline LSD at $0.05 \% 5 \%(\mathrm{~T})$ & \multicolumn{2}{|c|}{2.07} & & \multicolumn{2}{|c|}{2.51} & \\
\hline LSD at $5 \%(\mathrm{G})$ & \multicolumn{2}{|c|}{1.99} & & \multicolumn{2}{|c|}{2.83} & \\
\hline LSD at $5 \%(\mathrm{~T} \times \mathrm{G})$ & \multicolumn{2}{|c|}{2.80} & & \multicolumn{2}{|c|}{4.00} & \\
\hline
\end{tabular}

$* \mathrm{R} . \mathrm{D}=$ relative decrease in water stress over non stress condition 
Table 4. Mean performance for plant height and head diameter of sunflower genotypes grown under non stress and water stress conditions

\begin{tabular}{|c|c|c|c|c|c|c|}
\hline \multirow{2}{*}{ Genotypes } & \multicolumn{2}{|c|}{ Plant height $(\mathrm{cm})$} & \multirow{2}{*}{ R.D.* } & \multicolumn{2}{|c|}{ Head diameter $(\mathrm{cm})$} & \multirow{2}{*}{ R.D* } \\
\hline & Non-stress & Water-stress & & Non-stress & Water-stress & \\
\hline Charnika & 138.40 & 121.33 & -17.07 & 21.66 & 15.33 & -6.33 \\
\hline Thatta & 145.07 & 132.00 & -13.07 & 22.26 & 13.33 & -8.93 \\
\hline $\mathrm{A} 2$ & 131.47 & 116.33 & -15.14 & 21.33 & 13.33 & -8.00 \\
\hline TJ-1 & 155.13 & 136.33 & -18.8 & 21.80 & 17.00 & -4.80 \\
\hline $\mathrm{N}-17$ & 137.87 & 121.33 & -16.54 & 18.60 & 13.00 & -5.60 \\
\hline A-1 & 147.07 & 118.00 & -29.07 & 20.200 & 14.66 & -5.54 \\
\hline Mean & 142.50 & 124.22 & 18.28 & 20.97 & 14.44 & 6.53 \\
\hline LSD at $0.05 \%(\mathrm{~T})$ & \multicolumn{2}{|c|}{6.16} & & \multicolumn{2}{|c|}{3.07} & \\
\hline LSD at $5 \%(\mathrm{G})$ & \multicolumn{2}{|c|}{1.42} & & \multicolumn{2}{|c|}{1.30} & \\
\hline LSD at $5 \%(\mathrm{~T} \times \mathrm{G})$ & \multicolumn{2}{|c|}{2.01} & & \multicolumn{2}{|c|}{1.84} & \\
\hline
\end{tabular}

Table 5. Mean performance form number of seed head and 1000 seed weight of sunflower genotypes grown under non stress and water stress conditions

\begin{tabular}{|c|c|c|c|c|c|c|}
\hline \multirow{2}{*}{ Genotypes } & \multicolumn{2}{|c|}{ Number of seed head ${ }^{-1}$} & \multirow{2}{*}{ R.D.* } & \multicolumn{2}{|c|}{1000 seed weight $(g)$} & \multirow{2}{*}{ R.D* } \\
\hline & $\begin{array}{l}\text { Non- } \\
\text { stress }\end{array}$ & $\begin{array}{c}\text { Water- } \\
\text { stress }\end{array}$ & & Non-stress & Water-stress & \\
\hline Charinka & 876.67 & 643.33 & -233.34 & 56.00 & 31.00 & -25.00 \\
\hline Thatta & 850.00 & 730.00 & -120.00 & 53.00 & 27.00 & -26.00 \\
\hline $\mathrm{A} 2$ & 908.33 & 731.67 & 176.66 & 66.66 & 25.00 & -14.66 \\
\hline TJ-1 & 847.67 & 715.00 & -132.67 & 61.33 & 28.00 & -33.33 \\
\hline $\mathrm{N}-17$ & 725.00 & 566.67 & -158.33 & 46.66 & 32.00 & -14.83 \\
\hline A-1 & 808.33 & 720.00 & -88.33 & 51.33 & 31.00 & -20.33 \\
\hline Mean & 580.44 & 684.44 & -92.66 & 55.83 & 18.50 & -22.35 \\
\hline LSD at $5 \%(\mathrm{~T})$ & \multicolumn{2}{|c|}{41.95} & & \multicolumn{2}{|c|}{0.82} & \\
\hline $\mathrm{LSD}$ at $5 \%(\mathrm{G})$ & \multicolumn{2}{|c|}{25.18} & & \multicolumn{2}{|c|}{1.35} & \\
\hline LSD at $5 \%(\mathrm{~T} \times \mathrm{G})$ & \multicolumn{2}{|c|}{35.61} & & \multicolumn{2}{|c|}{1.91} & \\
\hline
\end{tabular}

$*$ R.D $=$ relative decrease in water stress over non stress condition 
Table 6. Mean performance for relative water content and leaf area of sunflower genotypes grown under non stress and water stress conditions

\begin{tabular}{|c|c|c|c|c|c|c|}
\hline \multirow{2}{*}{ Genotypes } & \multicolumn{2}{|c|}{ Relative water content (\%) } & \multirow{2}{*}{ R.D.* } & \multicolumn{2}{|c|}{ Leaf area $\left(\mathrm{cm}^{-2}\right)$} & \multirow{2}{*}{ R.D* } \\
\hline & Non-stress & Water-stress & & Non-stress & $\begin{array}{l}\text { Water- } \\
\text { stress }\end{array}$ & \\
\hline Chranika & 71.00 & 42.66 & -28.33 & 36.20 & 26.00 & -10.20 \\
\hline Thatta & 76.66 & 50.00 & -26.66 & 36.60 & 23.00 & -13.20 \\
\hline $\mathrm{A} 2$ & 80.00 & 40.00 & -40.00 & 37.60 & 30.00 & -7.60 \\
\hline $\mathrm{TJ}-1$ & 72.00 & 36.00 & -36.00 & 37.00 & 32.00 & -5.00 \\
\hline $\mathrm{N}-17$ & 75.00 & 39.33 & -35.66 & 36.06 & 25.66 & -10.40 \\
\hline A-1 & 77.00 & 46.00 & -31.00 & 38.23 & 31.00 & -7.23 \\
\hline Mean & 75.27 & 42.33 & -32.94 & 43.21 & 27.94 & 8.93 \\
\hline LSD at $5 \%(\mathrm{~T})$ & \multicolumn{2}{|c|}{1.26} & & \multicolumn{2}{|c|}{2.01} & \\
\hline LSD at $5 \%(\mathrm{G})$ & \multicolumn{2}{|c|}{1.48} & & \multicolumn{2}{|c|}{1.13} & \\
\hline $\mathrm{LSD}$ at $5 \%(\mathrm{~T} \times \mathrm{G})$ & \multicolumn{2}{|c|}{2.09} & & \multicolumn{2}{|c|}{1.60} & \\
\hline
\end{tabular}

$*$ R.D = relative decrease in water stress over non stress condition

Table 7. Mean performance for head mass and mass of achenes head ${ }^{-1}$ of sunflower genotypes grown under non stress and water stress conditions

\begin{tabular}{|c|c|c|c|c|c|c|}
\hline \multirow{2}{*}{ Genotypes } & \multicolumn{2}{|c|}{ Head mass (g) } & \multirow{2}{*}{ R.D* } & \multicolumn{2}{|c|}{$\begin{array}{c}\text { Mass of achenes head }^{-1} \\
(\mathrm{~g})\end{array}$} & \multirow{2}{*}{ R.D* } \\
\hline & non -stress & water -stress & & non -stress & water -stress & \\
\hline Charinka & 127.67 & 83.00 & -44.67 & 76.00 & 44.00 & -32.00 \\
\hline Thatta & 155.00 & 92.33 & -62.667 & 66.40 & 40.00 & -26.40 \\
\hline $\mathrm{A} 2$ & 185.00 & 76.00 & -109.00 & 82.96 & 46.33 & -36.63 \\
\hline TJ-1 & 132.33 & 65.00 & -67.33 & 73.33 & 40.33 & -33.00 \\
\hline $\mathrm{N}-17$ & 145.33 & 69.00 & -76.33 & 62.33 & 37.00 & -25.33 \\
\hline A-1 & 162.67 & 74.00 & -86.67 & 58.40 & 32.00 & -26.40 \\
\hline Mean & 151.33 & 76.72 & -74.44 & 69.90 & 39.94 & -29.96 \\
\hline LSD at $5 \%(\mathrm{~T})$ & \multicolumn{2}{|c|}{3.84} & & \multicolumn{2}{|c|}{1.68} & \\
\hline LSD at $5 \%(\mathrm{G})$ & \multicolumn{2}{|c|}{3.15} & & \multicolumn{2}{|c|}{1.34} & \\
\hline LSD at $5 \%(\mathrm{~T} \times \mathrm{G})$ & \multicolumn{2}{|c|}{4.45} & & & & \\
\hline
\end{tabular}

$*$ R.D $=$ relative decrease in water stress over non stress condition 
Table 8. Mean performance for biological yield plant ${ }^{-1}$ and harvest index of sunflower genotypes grown under non stress and water stress conditions

\begin{tabular}{|c|c|c|c|c|c|c|}
\hline \multirow{2}{*}{ Genotypes } & \multicolumn{2}{|c|}{ Biological yield plant ${ }^{-1}(\mathrm{~g})$} & \multirow{2}{*}{ R.D.* } & \multicolumn{2}{|c|}{ Harvest index (\%) } & \multirow{2}{*}{ R.D* } \\
\hline & Non-stress & Water-stress & & Non-stress & Water-stress & \\
\hline Charinka & 206.33 & 155.00 & --51.33 & 36.83 & 28.40 & -8.40 \\
\hline Thatta & 217.87 & 171.67 & -46.20 & 30.47 & 23.30 & -7.17 \\
\hline $\mathrm{A} 2$ & 256.00 & 162.67 & -93.33 & 32.41 & 28.48 & -3.93 \\
\hline TJ-1 & 258.67 & 192.67 & -66.00 & 28.35 & 20.94 & -7.41 \\
\hline $\mathrm{N}-17$ & 237.67 & 177.67 & -60.00 & 26.23 & 20.82 & -5.41 \\
\hline A-1 & 245.67 & 167.67 & -78.00 & 23.77 & 19.09 & -4.68 \\
\hline Mean & 222.21 & 171.22 & -65.18 & 29.67 & 23.50 & 6.16 \\
\hline LSD at $5 \%(\mathrm{~T})$ & \multicolumn{2}{|c|}{2.47} & & & & \\
\hline LSD at $5 \%(\mathrm{G})$ & \multicolumn{2}{|c|}{3.68} & & & & \\
\hline LSD at $5 \%(\mathrm{~T} \times \mathrm{G})$ & \multicolumn{2}{|c|}{5.21} & & & & \\
\hline
\end{tabular}

$*$ R.D = relative decrease in water stress over non stress condition

Table 9. Correlation coefficient mass of achenes head $^{-1}$ with yield and physiological traits grown under non-stress and water stress conditions

\begin{tabular}{|c|c|c|}
\hline Characters & Non-stress & Water stress \\
\hline Days to 75\% flowering & $-0.49^{*}$ & -0.15 \\
\hline Days to 75\% maturity & -0.28 & -0.20 \\
\hline Plant height & -0.01 & $-0.40^{*}$ \\
\hline Head diameter & -0.02 & $0.44^{*}$ \\
\hline Number of seed head $^{-1}$ & 0.10 & $0.73^{* *}$ \\
\hline 1000 seed weight & $-0.57^{*}$ & $0.87^{* *}$ \\
\hline Relative water content $_{\text {Leaf area }}$ & $-0.44^{*}$ & 0.02 \\
\hline Head mass & -0.11 & -0.10 \\
\hline Biological yield plant $^{-1}$ & 0.22 & $-0.36^{*}$ \\
\hline Harvest index & 0.29 & 0.09 \\
\hline
\end{tabular}

$* * * * \mathrm{P} \leq 0.01$ and 0.05 levels

\section{Conclusion}

The mean square from analysis variance displayed that genotypes, treatments and treatments $\times$ genotypes were Significant for all the traits like days to $75 \%$ heading, days to $75 \%$ maturity, plant height, number of seeds head $^{-1}$, 1000-seed weight, relative water content, leaf area, biological yield plant $^{-1}$, head mass, mass of achenes head ${ }^{-1}$ and harvest index. Water stress caused significant impacts on all the studies traits, like days to $75 \%$ heading, days to $75 \%$ maturity, plant height, number of seeds head 1 , 1000-seed weight, relative water content, leaf area, biological yield plant $^{-1}$, head mass, mass of achenes head ${ }^{-1}$ and harvest index. Among the genotypes such as A-2, A-1 and TJ-1 performed better under water stress conditions according to higher mean performance for all the studied traits.

\section{Authors' contributions}

Conceived and designed the experiments: FK Rajper, WA Jatoi, QAChanna \& S Memon, Performed the experiments: N Fatima \& MA Ansari, Analyzed the data: MM Lund \& S Keerio, Contributed materials/ analysis/ tools: K Mirani, Wrote the paper: WA Jatoi. 


\section{Referances}

1. Kibazohi O, R-P LE, Felix E \& CardonaAlzate CA (2012). Technical and economical analysis for biofuel production from sunflower. In Bioenergy and food security: The BEFS analysis for TanzaniaSunflower biodiesel, water, and household food security. Tanzania: FAO 108 (Ed FAO).

2. Rasool F, Hassan B \& Jahangir A (2013). Growth and yield of sunflower (Helianthus annus L.) as influenced by nitrogen, sulphur and farmyard manure under temperate conditions. SAARC J of Agric 11(1): 81-89.

3. Tahir M, YounasIshaq M, Sheikh A, Naeem M \& Rehman A (2014). Effect of boron on yield and quality of sunflower under agroecological conditions of Faisalabad (Pakistan). Sci Agric 7(1): 19-24.

4. Kunduraci B S, Bayrak A, \& Kiralan M (2010). Effect of essential oil and extracts from oregano (Origanum onites L.) leaves on the oxidative stability of refined sunflower oil. Asian Journal of Chemistry, 22:1377-1386.

5. Muller MH, Latreille M \& Tollon C (2011). The origin and evolution of a recent agricultural weed: population genetic diversity of weedy populations of sunflower (Helianthus annuus L.) in Spain and France. Evolu Applic 4: 499-514.

6. Rosegrant MW, Cai X \&Cline SA (2002). World Water and Food to 2025. Dealing with Scarcity. Intl Food Policy Res Inst, Washington, DC.

7. Rockström J, Falkenmark M, Karlberg L, Hoff H, Rost S \& Gerten D (2009). Future water availability for global food production: the potential of green water for increasing resilience to global change. Water Res Res 45:7.

8. Sarkar AA \& Ali MH (2009). Water table dynamics of Dhaka city and its long-term trend analysis using the "Makesense" model. Water Inter 34(3): 373-382.
9. Ashraf T \& Ali MH (2015). Water table dynamics and trend in three Upazilas of Rajshahi district (Barind area), Bangladesh. Asian Acad Res J Multidiscip 2: 286-310.

10. Alqudah AM, Samarah NH \& Mullen RE (2010). Drought stress effect on crop pollination, seed set, yield and quality. - In: Lichtfouse, E (ed.) Alternative Farming Systems, Biotechnology, Drought Stress and Ecological Fertilization. Berlin: Springer 193-213.

11. Islam MS, Akhter MM, EL Sabagh, Liu A, Nguyen LY, Ueda NT \& Saneoka AH (2011). Comparative studies on growth and physiological responses to saline and alkaline stresses of Foxtail millet (Setaria italica L.) and Proso millet (Panicum miliaceum L.). Aus J of Crop Sci 5(10): 1269-1277.

12. Jaleel CA, Manivannan $P$, Sankar B, Kishorekumar A, Gopi A, Somasundaram R \& Panneerselvam R (2007). Induction of droughtstress tolerance by ketoconazole in Catharanthus roseus is mediatedby enhanced antioxidant potentials and secondary metaboliteaccumulation. Colloids Surf B: Biointerfaces 60: 201-206

13. Zhu J K (2002). Salt and drought stress signal transduction in plants. Annu Rev Plant Biol 53: 247-273.

14. Razmjoo K, Heydarizadeh P \& Sabzalian MR (2008). Effect of salinityand drought stresses on growth parameters and essential oil contentof Matricaria chamomile. Inter J Agric Biol 10: 451-454.

15. Blum A (1996). Constitutive traitsaffecting plant performance under stress.

16. Smirnoff N (1993). The role of active oxygen in the response of plants to water deficit and desiccation. New Phytol 125: 2758.

17. Jaleel CA, Manivannan P, Lakshmanan GMA, Gomathinayagamand M \& Panneerselvam R (2008). Alterations in morphologicalparameters and photosynthetic pigment responses of 
Catharanthusroseus under soil water deficits. Colloids Surf B: Biointerfaces, 61: 298-303.

18. Thomaz GL, Zagonel J, Colasante LO \& Nogueira RR (2012). Yield of sunflower and oil seed content as a function of air temperature, rainfall and solar radiation. Ciência Rural 42: 1380-1385.

19. Ghaffari M, Toorchi M, Valizadeh M \& Shakiba MR (2012). Morpho-physiological screening of sunflower inbred lines under drought stress condition. Turk $J$ of Field Crops 17: 185-190.

20. Gholamhoseini M, Ghalavand A, Dolatabadian A, Jamshidi E \& KhodaeiJoghan A (2013). Effects of arbuscular mycorrhizal inoculation on growth, yield, nutrient uptake and irrigation water productivity of sunflowers grown under drought stress. Agric Water Manage 117: 106-114.

21. USDA. 2012 United States Department of Agriculture Oilseeds world markets and trade. Washington. September.

22. CONAB. 2016. National Food Supply Company. Monitoring of the Brazilian harvest Brasília: CONAB 2016. Accessed date: 20 September 2016.

23. Erdem T, Erdem Y, Orta AH \& Okursoy H (2006). Use of a crop water stress index for scheduling the irrigation of sunflower (Helianthus annuus L.). Turk J of Agricu and Fore 30:11-20.

24. Nezami A, Khazaei HR, Boroumand RZ \& Hosseini A (2008). Effects of drought stress and defoliation on sunflower (Helianthus annuus) in controlled conditions. J Desert (Biaban) 12 (2): 99-104.

25. Hussain S, Saleem MF, Iqbal J, Ibrahim M, Atta S, Ahmed T \& Rehmani M (2014). Exogenous application of abscisic acid may improve the growth and yield of sunflower hybrids under drought. Pak J of Agric Sci 51: 1-10.

26. McMaster GS, Ascough JC, Edmunds DA, Nielsen DC \& Prasad PV (2013). Simulating crop phenological responses to water stress using the PhenologyMMS software program. Appl Engi in Agric 29: 233-249.

27. Nel A, Loubser H \& Hammes P (2001). The effect of water stress during grain filling on the yield and processing quality of sunflower seed. S Afri J of Plant and Soil 18: 114-117.

28. Stone LR, Goodrum DE, Jaafar MN \& Khan AH (2001). Rooting front and water depletion depths in grain sorghum and sunflower. Agronomy J 93: 1105-1110.

29. Flagella Z, Rotunno T, Tarantino E, Di Caterina R \& De Caro A (2002). Changes in seed yield and oil fatty acid composition of high oleic sunflower (Helianthus annuus L.) hybrids in relation to the sowing date and the water regime. Eur J of Agro 17: 221-230.

30. Achakzai A (2009). Effect of water stress on imbibition, germination and seedling growth of maizecultivars. Sarhad J Agric 25: 165172.

31. Ahmad S, Ahmad R, Ashraf MY, Ashraf M \& Waraich EA (2009). Sunflower (Helianthus annuus L.) response to drought stress at germination and seedling growth stages. Pak J Bot 41: 647-654.

32. Hladni N, Jocić S, Miklič V, Mijić A \& Saftić-Panković D (2008). Direct and indirect effects of morphophysiological traits on seed yield of sunflower (Helianthus annuus L.). Pages 393-397 in Proc. 17th Int. Sunf. Conf., Cordoba, Spain, 1.

33. Mahmood H, Towfiq S \& Rashid K (2019). Water use efficiency of different sunflower genotypes under deficit irrigation in a semiarid region. Appl Ecol and Environ Res 17: 2043-2057.

34. Gomez KA \& Gomez AA (1984). Statistical procedures for agricultural research. John Wiley \& Sons, Inc. $2^{\text {nd }}$ Eds.

35. Raghavrao R (1983). Statistical techniques in agricultural and biological research.(In) Designing of Experiments. ed.: Oxford \& IBH Publishing Co. Pvt Ltd, New Delhi. 1983. 
36. Kalukhe V, Moon M, Magar N \& Patil S (2010). Character association and path analysis for seed yield in sunflower (Helianthus annuus L.). Inter J of Plant Sci (Muzaffarnagar) 5: 594-598.

37. Alahdadi I \& Oraki H (2011). Effect of water stress on yield and yield components of sunflower hybrids. Afri J of Biotechnol 10(34): 6504-6509.

38. Arshad M, Khan M A, Ullah I \& Amjad M (2013). Development of short duration and high yielding indigenous sunflower (Helianthus annuus L.) hybrids. Sci Tech Dev 32: 205-214.

39. Hussain S, Saleem M, Iqbal J, Ibrahim M, Ahmad M, Nadeem S, Ali A \& Atta S (2015). Abscisic acid mediated biochemical changes in sunflower (Helianthus annuus L.) grown under drought and well-watered field conditions. The J of Ani and Plant Sci 25: 406-416.

40. Buriro M, Sanjrani A, Chachar Q, Chachar N, Chachar S, Buriro B \& Mangan T (2015). Effect of water stress on growth and yield of sunflower. J of Agric Technol 11(7): 15471563.

41. Mobasser HR \& Tavassoli A (2013). Effect of water stress on quantitative and qualitative characteristics of yield in sunflower (Helianthus annuus L.). $J$ of Novel Appl Sci 2(9): 299-302.

42. Hemmati MH \& Soleymani A (2014). A study about drought stress effects on grain yield components of three sunflower cultivars, 564-572.

43. Killi TF (2016). Seed yield and some yield components of sunflower (Helianthus annuusL.) genotypes in Kahramanmaras (Turkey) conditions. $J$ of Sci and Engi Res 3(4): 346-349.

44. PekcanV, Evci G, Yilmaz MI, Nalcaiyi AS B, Erdal S, Cicek N, Arslan O, Ekmekci Y \& Kaya Y (2016). Effects of drought stress on sunflower stems and roots. Pages 4-5 in International Conference on Chemical, Agricultural and Life Sciences (CALS-16) Feb.

45. Saremirad A \& Mostafavi K (2020). Study of Genetic and Phenotypic Diversity of Sunflower (Helianthus annus L.) Genotypes for Agro-morphological Traits under Normal and Drought Stress Conditions.

46. Mahpara S, Bashir MA, Kamaran S, Irfanullah M, Salman S, Khan FU \& Shahnawaz M (2019). Genetic response of diverse sunflower genotypes in contrasting moisture regimes for various physiological and growth parameters at early developmental stage. Pure and Appl Biol 8 (1): 820-837.

47. Chambo ED, Escocard de Oliveira NT, Garcia,R.C, Ruvolo-Takasusuki MCC \& de Toledo VAA (2017). Phenotypic correlation and path analysis in sunflower genotypes and pollination influence on estimates. Open Biol Sci J 3(3): 1-15. 